\title{
PADRŌES DE ASSEPSIA UTILIZADOS NA UNIDADE DE INTERNAÇÃO E SALA CIRÚRGICA DOS PACIENTES DESTINADOS À ARTROPLASTIA DE QUADRIL
}

Autores:

Ana Maria Palermo da Cunha (1)

Carlos Solé-Vernin (2)

Isabel Amélia Costa Mendes (1)

Maria Aparecida Teixeira Roque (3)

Maria Ignez R. O. Ciconelli (4)

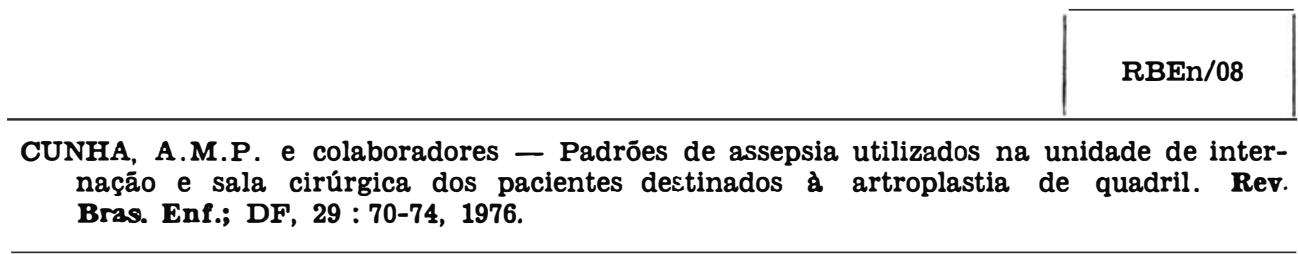

O preparo do paciente e da equipe cirúrgica não é suficiente para assegurarmos o êxito de qualquer procedimento cirúrgico.

Não podemos realizar o preparo do paciente para o ato cirúrgico sem preocuparmo-nos com detalhes inerentes ao preparo do ambiente hospitalar, unidade de internação do paciente e sala sirúrgica.

MAESTRE e colaboradores (1972) em seus trabalhos já recomendavam medidas que pudessem prevenir a infecção pós-operatória, como: limitar o número de colaboradores na Sala de Operação; controlar a renovação de ar da sala; eliminar conversas desnecessárias.

HERRERO (1972) confirmou em seus estudos o rigor da assepsia cirúrgica tanto na sala de operação como em todo o ambiente cirúrgico que acolha o paciente. Preconizou uma assepsia cuidadosa e sem meio termos exigindo da instrumentadora da equipe que executasse a tarefa de advertir com firmeza as

(1) Professor -Assistente do Departamento de Enfermagem Geral e Especializada da Escola de Enfermagem de Ribeirāo Preto da Universidade de Sāo Paulo.

(2) Professor-Titular de Microbiologia do Departamento de Parasitologia, Microbiologia e Imunologia da Faculdade de Medicina de Ribeirāo Preto.

(3) Enfermeira responsável pelo Centro Cirúrgico do Hospital das Clínicas de Ribeirāo Preto.

(4) Professora responsável pela disciplina de Enfermagem Cirúrgica do Departamento de Enfermagem Geral e Especializada da Escola de Enfermagers de Ribeirāo Preto, da Universidade de São Paulo. 
CUNHA, A.M.P. e colaboradores - Padrōes de assepsia utilizados na unidade de internaçāo e sala cirúrgica dos pacientes destinados à artroplastia de quadril. Rev. Bras. Enf.; DF, 29 : 70-74, 1976.

irregularidades involuntárias que pudessem prejudicar o padrão de assepsia desejado nas artroplastias de quadril.

CHARNLEY (1964) chegou a idealizar uma corrente laminar de ar estéril, que passando por hiperpressão através de filtros capazes de reter partículas de até um micron de tamanho, que impediria a veiculação das bactérias.

O meio ambiente pode tornar-se elemento desancadeante na propagação da infecção, se for descuidada a forma de tratamento que receber concomitante com assistência de enfermagem prestada ao paciente.

Neste trabalho padronizamos técnicas de limpeza e desinfecção para o meio ambiente, de modo a proporcionar maior segurança para atendimento do paciente cirúrgico.

\section{MATERIAL E METODO}

\section{Ambiente:}

Para receber os pacientes a serem submetidos à artroplastia do quadril, foi organizada uma unidade especial de internação. Neste local os pacientes permaneceram durante todo o período de hospitalização que, em média, fol de 15 dias: 3 de pré e 12 de pós-operatório.

0 acesso à enfermaria era rigorosamente controlado, sendo obrigatório o uso de avental e proteção para os pés no seu interior.

A unidade de internação era composta de um quarto com dois leitos, um banheiro privativo e uma ante-sala. Possuir ventilação e lluminação adequadas, oxigênio e vácuo com sistema central.

Tanto a unidade de internação como a sala cirúrgica receberam a limpeza diária, desinfecção e sempre antes da entrada do paciente receberam tratamento do ar ambiente.

A equipe médica $e$ de enfermagem usou composto quaternário de amônio como antisséptico para degermar as mãos antes de qualquer tratamento do paciente.

Limpeza de Ambiente: (Pessoal serviçal)

Compreendemos por Ambiente: Unidade de Internação do paciente, Salas de Operações, corredores e vestíbulos do hospital, Posto de Enfermagem, Salas de Atendimento de Paciente etc.

Diariamente Limpar: Foi lavado com água e sabão, enxaguado e enxuto cuidadosamente as paredes de azulejo, parapeitos e janelas e o chão.

Nota: Exaguor-se principalmente cantos, rodapés e pés do mobiliário.

Semanalmente: Além da limpeza diária, limpou-se globo de luz, portas, janelas e vitrôs, armários, tetos e paredes sem azulejo.

Nota: Para a limpeza de tetos e paredes usamos um pano limpo e úmido enrolado em vassoura própria a fim de remover a poeira.

O balde, os panos e a água com sabão usados estavam sempre limpos. Quando a água apresentava-se turva e o pano sujo, foi substituída a água e lavado o pano para prosseguir a limpeza.

\section{Limpeza diária de ambiente: (Pessoal de Enfermagem)}

Foi lavado com água e sabão, enxaguado e enxuto todo o mobiliário e equipamentos que compunham a Unidade de Internação do Paciente, Sala de Operações e Sala de Atendimento de pacientes.

\section{Desinfeç̧ão de Ambiente (Pessoal de Enfermagem) \\ Material: \\ 1 avental com mangas compridas, 1 par de botas, 1 par de luvas, 1 balde, 1 rodo, 1 pano, 1 cálice graduado LIM- POS e o desinfetante *.}

- Desinfetante - Duo-Cide SP-Darrow Laboratórios S.A. Divisāo de Antissépticos. Marca Registrada - Rio de Janeiro, RJ. 
CUNHA, A.M.P. e colaboradores - Padrōes de assepsia utilizados na unidade de internaçāo e sala cirúrgica dos pacientes destinados à artroplastia de quadril. Rev. Bras, Ene.; DF, 29 : 70-74, 1976.

Preparou-se uma solução a $2 \%$ do desinfetante usado, fol passado nas paredes de azulejo, parapeitos de janelas, mobiliário e chāo.

Nota: Sempre que a solução desinfetante apresentou-se turva fol substituida.

\section{Desinfetante usado}

Fórmula: Formaldeído-álcool, Cloreto de Benzetônico, Isto-octil-fenoxi-polietoxietanol; Veículo aquoso.

\section{Tratamento do Ar Ambiente}

Fol feito semanalmente com remoçāo do paciente ou sempre que a situação exigiu.

Material: Soluçāo desinfetante usada: Vaporizador para ambiente Cálice Graduado.

Uso: Para cada $\mathrm{m}^{3}$ de amblente $5 \mathrm{ml}$ da solução desinfetante usada.

O tratamento do ar amblente fol feito após a limpeza e desinfecção do mesmo. Após vaporização da quantidade de desinfetante determinada para o amblente, fol fechado por sessenta minutos. Decorrido este tempo, fol arejado e usado 0 ambiente.

Notas: Gavetas, portas de armários, permaneceram abertas totalmente para permitir exposição de suas superfícies.

Fol vaporizado o ambiente em movimentos circulares, cada círculo passou sucessivamente de uma parede a outra, em uma área próxima ao teto, abrangendo todo o ambiente e pela lel da gravidade as gotículas pulverizadas chegavam a áreas mais baixas e até o chão. $\mathrm{Na}$ ausência de uma bomba adequada para vaporizar, poderāo ser utllizados vários vaporizadores, colocados o mais próximo possível do teto, de modo a abranger todo o ambiente.

\section{Material para colheita}

Foram utilizadas placas Rodac * com melo de cultura agar-infusão-sangue (coelho) para cultura de material colhido nas diversas áreas do ambiente.

Para neutralizar o efeito bacteriostático-bactericida dos resíduos do desinfetante, adicionamos aos melos de cultura: Tween, 80 a $1 \%$ e Gema de ovo a $0,5 \%$ no melo de Agar-Sangue.

Após a colheita do material, as placas com Agar-Sangue foram incubadas em estufa a $35^{\circ} \mathrm{C}$ por 24 horas, após este tempo fol realizada a leitura das placas contando-se o número de colónias crescidas nas superfícies dos melos.

\section{Técnica para colheita de material}

Colhemos material do Amblente em duas Fases:

I Fase: - A unidade de internação ou sala cirúrgica encontrava-se suja, ou seja, após o uso dos ambientes.

II Fase: - A unidade de internação ou sala Cirúrgica estava pronta para uso, ou seja, após limpeza, desinfecção e tratamento do ar ambiente.

Locais determinados para colheita do material.

Colhemos material do piso e mobiliário dos ambientes observados.

Utilizamos as placas Rodac como carimbo de superficie para colher material dos locais referidos.

\section{RESULTADOS}

Os resultados referem-se aos primelros 10 pacientes observados no pré e pósoperatório, durante o período de $7 \mathrm{me}-$

- Rodac plates $15 \mathrm{~mm}$ Style. $6 \mathrm{~cm}$ de diametro. Falcon plastics Division of B-D Laborattories Inc. - Los Angeles - Califórnia. Sua conformação permite que as tampas das mesmas formem um encaixe, nāo tocando na superfície do Agar. Såo recuperados por lavagem e desinfecção quimica a frío (detergente, glutaraldeído $2 \%$ e álcool etillico $\mathbf{7 0 \%}$ ). 
CONHA, A.M.P. e colaboradores - Padróes de assepsia utilizados na unidade de inter-

naçāo e sala cirúrgica dos pacientes destinados à artroplastia de quadrul. Rev.

Bras, Enf.; DF, 29 : 70-74, 1976.

ses consecutivos, em que procuramos, de uma forma sistematizada, padronizar a desinfecção do ambiente.
Apresentaremos um caso como llustração dos resultados obtidos (Tabela I).

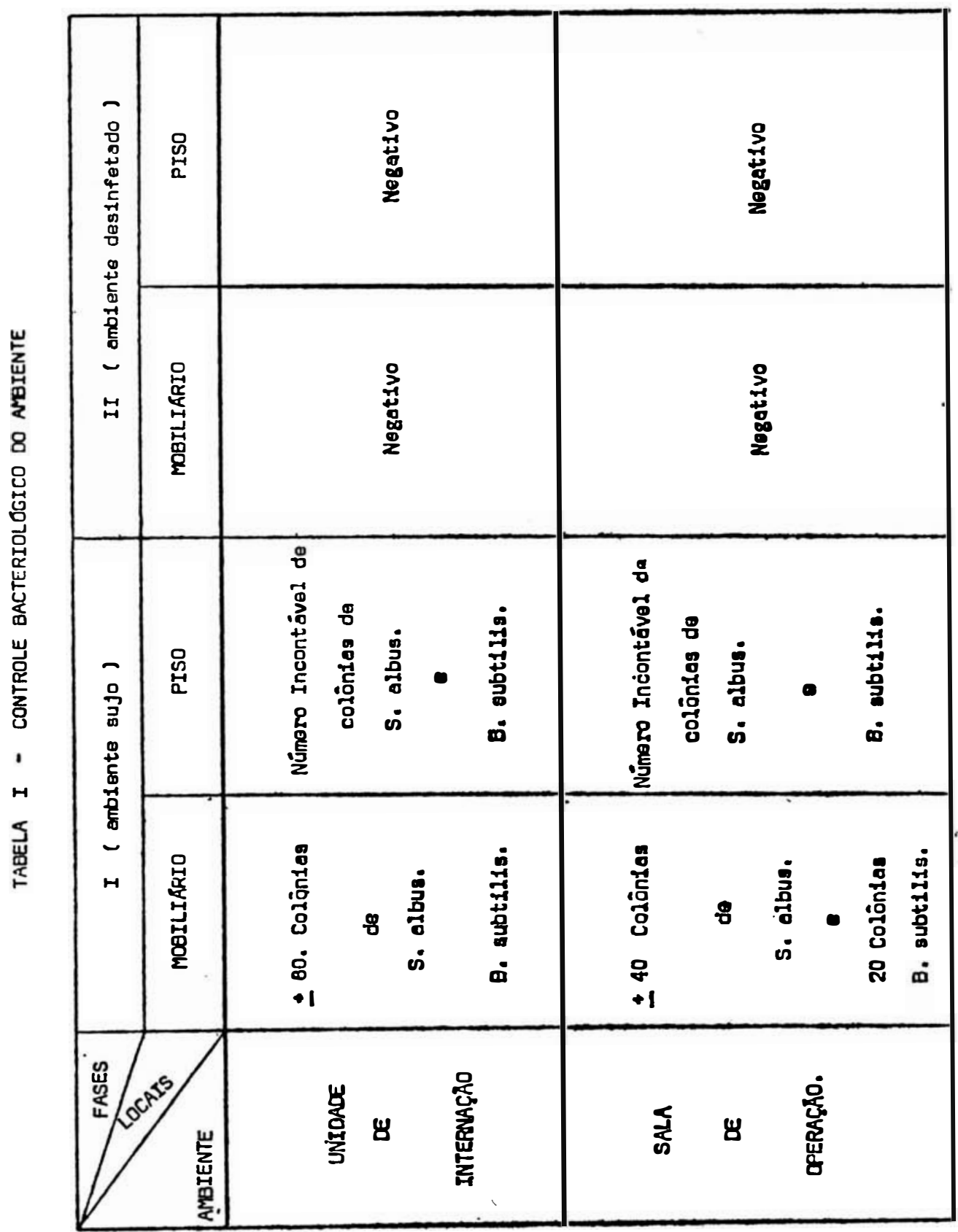


CUNHA, A.M.P. e colaboradores - Padrōes de assepsia utilizados na unidade de internação e sala cirúrgica dos pacienues destinados à artroplastia de quadril. Rev. Bras. Enf.; DF, 29 : 70-74, 1976.

\section{DISCUSSÃO}

Com a realização deste controle bacteriológico do ambiente pudemos constatar situaçōes, como mostra também a Tabela I, que após o uso de uma sala de operação e também de uma unidade de internação estas apresentaram-se com número incontável de colônias bacterianas para $S$ : albus e $B$. subtilis, no piso. O mobiliário de uma sala de operação, apesar da assepsia mantida no 'seu interior, após horas de exposição para a realização das cirurgias programadas também apresentou-se com número de colônias elevado conforme pode-se observar na Tabela I.

Com a realização deste trabalho concíuímos que a população bacteriana de um ambiente aumenta cada vez mais com as correntes de ar proporcionadas pela abertura da porta de entrada da unidade observada.

Outro fator que contribuiu muito para aumento de população bacteriana nos ambientes estudados foi o grande número de pessoas da equipe médica e de enfermagem que entravam para prestar assistência ao paciente. Na sala cirúrgica restringimos ao máximo o número de vezes em que a porta de entrada de- veria abrir-se, procurando equipar suficientemente a sala de operação, antes do ato cirúrgico e do tratamento do ar ambiente. Limitamos o número de colaboradores da equipe médica e da equipe de enfermagem para atuar durante o ato operatório. Conversas desnecessárias durante $o$ ato cirúrgico ficaram proibidas. Toda a equipe médica e de enfermagem que movimentava-se na sala de operação, fazia-o com calma e tranqüilidade evitando o deslocamento brusco de correntes de ar.

Na unidade de internação todos os elementos que tinham acesso à mesma para prestar assistência ao paciente, colocaram, sobre seus uniformes, um avental com mangas compridas, além de botas limpas protegendo o sapato. A degermação das mãos fol cuidadosa e o antisséptico empregado foi um composto quaternário de Amônio *.

\section{CONCLUSÃO}

O método de limpeza, desinfecção e tratamento do ar ambiente realizado foi suficiente para tratar convenientemente o ambiente cirúrgico, oferecendo segurança no pré, trans e pós-operatório dos pacientes submetidos à artroplastia do quadril.

\section{REFERENCIAS BIBLIOGRAFICAS}

1. CHARNLEY, J. - Clean a'r operating room enclosure. British Journal of Surgery. 51 - 1964.

2. Guia para controle de Infecçōes em Hospitais - Tract. New York State Department of Health. Porto Alegre, 1973.

3. MAFSTRE, J., Cañas, J., Vivas, J. \& Sachez Cra, V. - Astroplastia de cadera por endopróteses total encementada in "Técnicas Actuales en
Cirurgia Ortopédica y Tarumatológia". Maestre Herrero, J. y colaboradores. Artes Graficas Soler - Valencia - 1972.

4. MAESTRE, Herrero, J. - Eficiencia y rentabilidad quirurgica en un departamento de ortopedia $y$ traumatologia in "Técnicas Actuales en Cirurgia Ortopédica $\mathrm{J}$ Traumatologia". Maestre Herrero, J. J colaboradores. Artes Graficas Soler, Valencia 1972.

- Germ-Hand-Darrow Laboratórios S.A. Divisảo de Antissépticos, .Marca Registrada Rio de Janeiro, RJ. 